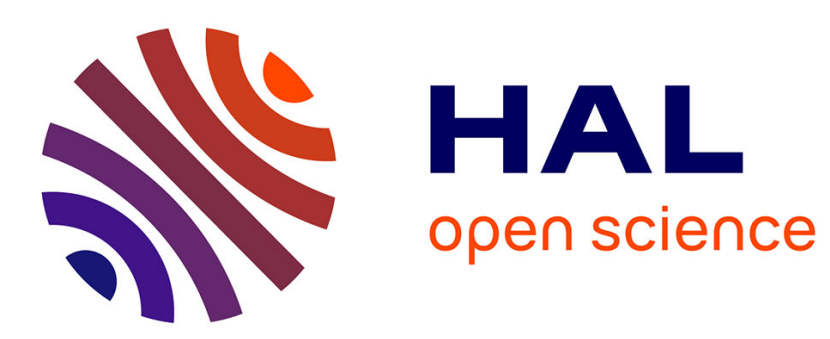

\title{
Information Literacy, Participatory Projects and the Development of Political Roles for Librarians
}

\author{
Raphaëlle C. Bats
}

\section{To cite this version:}

Raphaëlle C. Bats. Information Literacy, Participatory Projects and the Development of Political Roles for Librarians. Information Literacy: Key to an Inclusive Society. 4th European Conference, ECIL 2016, ECIL, Oct 2016, Prague, Czech Republic. hal-02476923

\section{HAL Id: hal-02476923 \\ https://hal.science/hal-02476923}

Submitted on 13 Feb 2020

HAL is a multi-disciplinary open access archive for the deposit and dissemination of scientific research documents, whether they are published or not. The documents may come from teaching and research institutions in France or abroad, or from public or private research centers.
L'archive ouverte pluridisciplinaire HAL, est destinée au dépôt et à la diffusion de documents scientifiques de niveau recherche, publiés ou non, émanant des établissements d'enseignement et de recherche français ou étrangers, des laboratoires publics ou privés. 
Raphaëlle Bats, ECIL

Résumé en français :

En 2015, la Bibliothèque municipale de Lyon a commencé la préparation d'un programme d'événement appelé "Démocratie : rêver, penser et agir ensemble ». Ce programme offrira entre novembre 2016 et mars 2017 près de 80 événements de toute nature, dont plus de la moitié sont participatifs. Pendant l'année de préparation, le comité de pilotage de ce programme a mis en place une veille autour de la participation pour se former et pour informer et former les équipes de la bibliothèque. Cet article est l'analyse de cette veille aussi bien en termes de sources, de médias que de contenus et d'auteurs. En m'appuyant sur la définition de la culture informationnelle telle que donnée par Olivier Le Deuff, j'ai étudié cette veille en trois temps. D'abord, j'ai cherché à voir si cette veille laissait apparaître une certaine définition de la participation que les bibliothécaires auraient retenue comme pertinente. Cette veille étant collaborative, elle s'appuyait sur des veilles individuelles mises en commun. J'ai cherché ensuite à déterminer la part des valeurs bibliothéconomiques dans la sélection qui était menée par des individus bibliothécaires. Et enfin, j'ai cherché à voir dans quelle mesure cette veille et ses modalités de diffusion créait des injonctions à l'action participative pour ses récepteurs.

Au terme de cette recherche, il semble que dans un projet comme celui mené par la BML, la recherche d'information menée par l'équipe organisatrice est révélatrice d'une nouvelle approche du rôle politique des bibliothèques. Elle dresse le portrait d'une nouvelle génération de bibliothécaires qui assume son rôle politique avec un sens élevé de la responsabilité des employés du service public culturel. Néanmoins, cette volonté de prendre part à l'action politique semble entrer en conflit avec un autre aspect de l'institution culturelle, qui est celui des valeurs qu'elle entend défendre et en premier lieu la notion de neutralité. Cette ambivalence très perceptible dans la veille qui est menée, et par conséquent dans la représentation que les bibliothécaires se font de la participation aura un impact non négligeable sur les formes des pratiques participatives qui seront mises en place. 


\section{Contents}

\section{Inclusive Society and Democracy}

Student Teachers' Perceptions of an Inclusive Future. . . . . . . . . . . . . 3 Ivana Batarelo Kokić, Terri L. Kurz, and Višnja Novosel

Gender Differences in ICT Use and Information Literacy in Public Libraries: A Study in a Rio de Janeiro Public Library . . . . . . . . . . . . . . . Aline Gonçalves da Silva and Gilda Olinto

The Searching Circle: Library Instruction for Tribal College Students . . . . . . Loriene Roy, Jain Orr, and Laura Gienger

Information Literacy, Participatory Projects and the Development

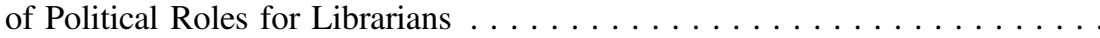

Raphaëlle Bats

Enhancing Financial Information Literacy in Italian Public Libraries:

A Preliminary Study . . . . . . . . . . . . . . . . . . .

Laura Ballestra and Piero Cavaleri

Re-Framing Information Literacy for Social Justice . . . . . . . . . . .

Laura Saunders

Ideological Views, Social Media Habits, and Information Literacy . . . . . . 66 Stjepan Lacković

\section{Employability and Workplace}

How Is Information Literacy Related to Social Competences in the Workplace?............................... Anne-Sophie Collard, Thierry De Smedt, Pierre Fastrez, Valèria Ligurgo, and Thibault Philippette

Information Literacy and Graduate Employability . . . . . . . . . . . . . . Stéphane Goldstein

Are We Speaking the Same Language? Croatian Employers' IL Competency Requirements for Prospective Employees. Mihaela Banek Zorica, Sonja Špiranec, and Vjeran Bušelić

How Groups Talk Information Literacy into Being . . . . . . . . . . . . . Andrew Whitworth, Maria Carme Torras i Calvo, Bodil Moss, and Nazareth Amlesom Kifle 
Knowledge Management and Information Literacy: An Exploratory

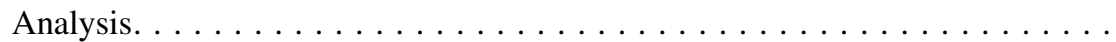

Sirje Virkus

\section{Various Literacies}

Citizen Science as an Educational Tool for Improving Scientific Literacy of Undergraduate Students . . . . . . . . . . . . . . . . . . . . .

Kristýna Kalmárová

Everyday Health Information Literacy of Young Finnish and Namibian

Students: Is There a Difference? . . . . . . . . . . . . . . . . . . . . . .

Maija-Leena Huotari, Heidi Enwald, Noora Hirvonen,

Cathrine Nengomasha, Ruth Abankwah, Wilhelm Uutoni, and Raimo Niemelä

English Language as a Promoter of Media Literacy Education . . . . . . . . . . Tihomir Živić and Tamara Zadravec

Social Media Networking Literacy and Privacy on Facebook:

Comparison of Pupils and Students Regarding the Public Availability

of Their Personal Information . . . . . . . . . . . . . . . . . .

Mirko Duić and Paula Džapo

Digital Literacy as a Boost Factor in Employability of Students . . . . . . . . . Radovan Vrana

Accessibility of Digital Information: Standards, Frameworks, and Tools

Related to Information Literacy and Information Technology . . . . . . . . . . Valentina Kirinić

Visual Literacy in Library Practice: Use of Images on the Facebook Pages

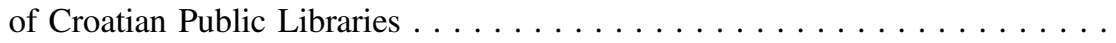
Mirko Duić

How Primary Teachers in Greece Seek Information: Use and Initial Appraisal of Information Resources. . . . . . . . . . . . . . . . . . .

Emmanouel Garoufallou, Stavroula Antonopoulou,

Ioanna-Ersi Pervolaraki, Rania Siatri, Georgia Zafeiriou, and Sirje Virkus

\section{Reading Preference: Print vs Electronic}

The Academic Reading Format International Study (ARFIS): Investigating Students Around the World . . . . . . . . . . . . . . . . . . . . . . .

Diane Mizrachi, Joumana Boustany, Serap Kurbanoğlu, Güleda Doğan, Tania Todorova, and Polona Vilar 
Print vs. Digital Preferences. Study Material and Reading Behavior of Students at the University of Iceland . . . . . . . . . . . . . . Ágústa Pálsdóttir and Sigriððu Björk Einarsdóttir

Print or Electronic? Estonian Students' Preferences in Their Academic Readings . . . . . . . . . . . . . . . . . . . . . . . . . Mai Põldaas

Print and Digital Reading Preferences and Behaviors of University Students in Qatar . . . . . . . . . . . . . . . . . . . . . . . . .

Nicole Johnston, Alicia Salaz, and Lana Alsabbagh

Academic Policy Reflections of Student's Reading Behavior Study

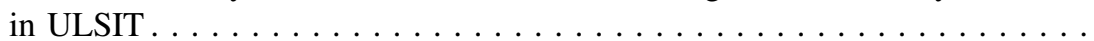

Tania Todorova, Rositza Krasteva, Tereza Trencheva, and Elisaveta Tsvetkova

\section{Theoretical Aspects}

Toward a Theory of Information Literacy: Information Science Meets Instructional Systems Design . . . . . . . . . . . . . . . Delia Neuman

Open Science and the Research Information Literacy Framework . . . . . . . . Jela Steinerová

The End of Information Literacy $(?) \ldots \ldots \ldots \ldots \ldots \ldots \ldots \ldots$ Michaela Dombrovská

Relationality Is the Key: The Family of Digital Competencies' Catalogues and Their Potential Applications . . . . . . . . . . . . . . . .

Małgorzata Kisilowska, Justyna Jasiewicz, and Anna Mierzecka

Information Literacy Competencies as Part of Content Curation 304 Terttu Kortelainen

\section{Higher Education}

Information Literate or Not?: A Nationwide Survey Among University Students in the Czech Republic. . . . . . . . . . . . . . . . . . . . . . . Hana Landová, Jitka Prajsová, and Ludmila Tichá

Assessing Spanish-Speaking University Students' Info-Competencies with iSkills, SAILS, and an In-House Instrument: Challenges and Benefits. . . Jesus Lau, Juan D. Machin-Mastromatteo, Alberto Gárate, and A. Cecilia Tagliapietra-Ovies 
Is There a Focus on Information Literacy as a Transversal Skill Within the Institutional Accreditation Process? . . . . . . . . . . . . . . . Elitsa Lozanova-Belcheva

How Information Literate Are We as Teachers? . . . . . . . . . . . . . . Jos van Helvoort and Ellen Sjoer

Searching as Strategic Exploration: How Well Do Faculty Know Their

Students' Opinions Regarding Information Sources? . . . . . . . . . . . . . . Katia G. Karadjova and Marissa M. Mourer

Novice and Expert Information Behavior: An Eye Tracking Study from Qatar

A.M. Salaz, Teresa MacGregor, and Priya Thomas

\section{Discipline Based Studies}

Views of Legal Scholars About the Concept of Information Literacy in the Field of Law: Case Study of a Law Faculty in the Republic of Croatia . . . . . Dejana Golenko

Information Literacy Programs in the Field of Law: Case Study of Two Law Faculties in Croatia ........................ Dejana Golenko, Kornelija Petr Balog, and Ljiljana Siber

Scaffolding Information Literacy in the Nursing Curriculum.

Eric Jennings, Hans Kishel, Bryan S. Vogh, Angie Stombaugh, Rita Sperstad, and Arin VanWormer

Assessing Content and Cognitive Levels of Information Literacy in a Group of Life Sciences University Students . . . . . . . . . . . . . . . . . . . .

Danica Dolničar, Bojana Boh Podgornik, Irena Sajovic, Andrej Šorgo, and Tomaž Bartol

How University Students in Health Care Look for Information:

Use and Initial Appraisal of Information Resources . . . . . . . . . . . . . . .

Emmanouel Garoufallou, Chrysanthi Chatzopoulou, Eleni Tzura,

Souzana Maranga, Rania Siatri, Georgia Zafeiriou, and Stavroula Antonopoulou

Self-reported Information Literacy Skills Among Researchers Within a Medical and Health Science Faculty . . . . . . . . . . . . . . . . . .

Ann De Meulemeester, Nele S. Pauwels, Renaat Peleman, and Heidi Buysse

Seeking Creativity: A Case Study on Information Problem Solving in Professional Music $\ldots \ldots \ldots \ldots \ldots \ldots \ldots \ldots \ldots$ 


\section{Research Methods}

Institute for Research Design in Librarianship: Impact on Information Literacy Research and Practice . . . . . . . . . . . . . . . . . . .

Lili Luo, Marie Kennedy, and Kristine Brancolini

\section{Children and Youth}

Use of Digital Tools by Preschool Children: Preliminary Results . . . . . . . . Ioanna-Ersi Pervolaraki, Emmanouel Garoufallou, Rania Siatri, Georgia Zafeiriou, Sirje Virkus, and Stavroula Antonopoulou

Expanding Children's Digital Literacy Experiences and Skills: Public Library Practices in Guangzhou, China . . . . . . . . . . . . . . . . . Qiong Tang, Cuihong $W u$, and Yantao Pan

Computer Science for the Community: Increasing Equitable Opportunity for Youth Through Libraries.

Marijke Visser and Hai Hong

Using I-LEARN to Foster the Information and Digital Literacies of Middle School Students . . . . . . . . . . . . . . . . . . . . . . . .

Vera J. Lee, Allen Grant, Delia Neuman, and Mary Jean Tecce DeCarlo

Exploring the Lived Experience of Middle School Students Engaged in Inquiry Based Learning $\ldots \ldots \ldots \ldots \ldots \ldots \ldots \ldots \ldots$ Shelly Buchanan

Teaching and Learning Information Literacy in Upper Secondary Schools in Vietnam . . . . . . . . . . . . . . . . . . . . . . . . . Huyen Thi Ngo, Geoffrey Lee Walton, and Alison Jane Pickard

Civic Action-Driven Information Literacy Instruction in Taiwan . . . . . . . . Lin Ching Chen and Yaw-Huei Chen

\section{Country Based Studies}

Information Competencies of Historians as Archive Users: A Slovenia/UK

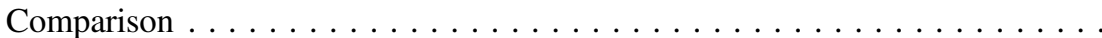
Polona Vilar, Alenka Šauperl, Zdenka Semlič Rajh, Lyn Robinson, and David Bawden

Developing Information Literacy Skills Lesson Plans Integrated into the $6^{\text {th }}$ Iranian Primary Science Curriculum Based on the Big6 Model . . . . . . . 
Integrating the Personal Information Culture Concept and the Idea of Media and Information Literacy Offered in the UNESCO Curriculum for Teachers:

Experiences of Russia and Uzbekistan . . . . . . . . . . . . Natalia Gendina

Information Literacy Instruction: An Overview of Research and Professional Development in Pakistan . . . . . . . . . . . .

Kanwal Ameen and Midrar Ullah

Public Policies for Information Literacy in Portugal:

An Agenda in the Making . . . . . . . . . . . . . . . . . . .

Tatiana Sanches

Action Plan for Improving the Learning Practices and Motivation of LIS Students. . . . . . . . . . . . . . . . . . . . . . . . . .

Tania Todorova, Elena Ignatova, and Irena Peteva

\section{Academic Libraries}

Intervening Conditions Inside and Outside Libraries in Order to Build Collaboration Between Teaching Faculty and Librarians in Education: Based on a Case Study of Earlham College . . . . . . . . . . . . . . . . Tayo Nagasawa

Information Literacy as a Key to Academic Success: Results from a Longitudinal Study . . . . . . . . . . . . . . . . . . Anne-Kathrin Mayer and Günter Krampen

Web 2.0 and Academic Libraries: A Survey Investigating Uptake Among University Students . . . . . . . . . . . . . . . . . . . . . . . . . 608 Emmanouel Garoufallou, Souzana Maranga, Chrysanthi Chatzopoulou, Eleni Tzura, Rania Siatri, Georgia Zafeiriou, and Stavroula Antonopoulou

\section{Librarians}

Librarians as Educators: Affective Dimensions Experienced in Teaching . . . . Vincas Grigas, Roma Fedosejevaite, and Anna Mierzecka

Copyright Literacy Competencies from Portuguese LIS Professionals . . . . . . Ana Lúcia Terra

Information Literacy Education and the Educational Needs of Teaching Librarians: The Czech Republic in Comparison with the Other Visegrad Four Countries . . . . . . . . . . . . . . . . . . . . . . . . . . . 
Effects of a Virtual Learning Environment on Librarians' Information

Literacy and Digital Literacy Competences. . . . . . . . . . . . . . . . .

Ana Novo, Glória Bastos, and Ana Isabel Vasconcelos

\section{Teaching Methods and Instruction}

Investigating the Guided Inquiry Process $\ldots \ldots \ldots \ldots \ldots \ldots$

Lee FitzGerald and Kasey L. Garrison

Teacher Perspectives on Whole-Task Information Literacy Instruction . . . . . . Iwan Wopereis, Jimmy Frerejean, and Saskia Brand-Gruwel

Information Literacy Dialogue as a Wittgensteinian Language-Game:

Embedding IL into Curricula Michael Flierl

Motivating Learners Through Information Literacy $\ldots \ldots \ldots \ldots \ldots \ldots \ldots$ Clarence Maybee and Michael Flierl

Mastering Information and Teaching Controversies: An Exploratory Study. . 708 Orélie Desfriches Doria and Madjid Ihadjadène

"Bibliostory-Educational Comic Stories." A Social Constructivist Approach to Media and Information Literacy Education for Children and Adolescents . . . . . . . . . . . . . . . . . . . . . . . .

Ewa A. Rozkosz and Zuza Wiorogórska

Assessing Awareness of Library Services: An Ethnographic Examination of Bachelor Students at Two Czech Technology Universities . . . . . . . . . .

Alena Chodounská and Stephanie Krueger

Erratum to: The Academic Reading Format International Study (ARFIS):

Investigating Students Around the World . . . . . . . . . . . . . .

Diane Mizrachi, Joumana Boustany, Serap Kurbanoğlu, Güleda Doğan,

Tania Todorova, and Polona Vilar 


\section{黛 Springer}

http://www.springer.com/978-3-319-52161-9

Information Literacy: Key to an Inclusive Society

4th European Conference, ECIL 2016, Prague, Czech

Republic, October 10-13, 2016, Revised Selected

Papers

Kurbanoğlu, S.; Boustany, J.i Špiranec, S.; Grassian, E.i

Mizrachi, D.i Roy, L.; Çakmak, T. (Eds.)

2016, XXI, 742 p. 87 illus., Softcover

ISBN: $978-3-319-52161-9$ 


\title{
Information Literacy, Participatory Projects and the Development of Political Roles for Librarians.
}

\author{
Raphaëlle Bats \\ 'Univ Lyon, Centre Gabriel Naudé, Enssib / \\ Univ Paris, LCSP, Paris Diderot, France \\ raphaelle.bats@enssib.fr
}

\begin{abstract}
This paper reports on information retrieved by a team of librarians of the public library of Lyon as part of their preparation for their involvement in a participatory project . I based the quantitative and qualitative analyses on a theoretical framework built on philosophy and information science concepts. My results shows that taking part in political action seems to be in conflict with some traditional values of libraries like neutrality, democratization, and emancipation through culture rather than through action. Finally my study lets us drawn the portrait of a new generation of librarians who accept their political role.
\end{abstract}

Keywords: participation, public libraries, political culture, expertise, librarianship

\section{Introduction}

For more than 20 years, in France, the public has regularly experimented in participating in urban renewal projects. For the past five years, cultural policies have expressed interest in in similar efforts. Libraries in particular have begun to embrace this new dynamic on their own initiative, on the initiative of elected officials, or, in rarer cases, on the initiative of associations. Municipal and national libraires have been especially eager to launched participatory projects in many fields such as acquisitions, heritage, event organization, and records correction. While participation seems to be legitimate in libraries, both philosophically and politically [1], librarians still are learing to view their services as new approaches in political action and agency. They are still beginning to consider their role as an emancipatory service in a public space,. The first reason is that participatory projects ${ }^{1}$ required equality between the public and the institution. Libraries are more used to an approach where they provide guidance in support of a top down education. The second reason is that participatory projects are an opportunity to practicedemocracy. This would require libraries to adopt a critical approach to the actual democracy, a critical position that is not in the habits of cultural institutions that claim neutrality.

\footnotetext{
1 I define a participatory project as a project where the patrons are actors and not only passive or consumers. We can measure participatory projects using Sherry Arnstein's [29] spectrum from non-participation, tokenism, and citizen control.
} 
The Bibliothèque Municipale de Lyon (BML) is the second largest public library in France after the Bibliothèque Nationale de France. It employs a staff of 500 and serves 14 branches and one central library. As early as 2014, the BML was envisioning a large cultural project on democracy. After the terrorist attacks in January 2015, the project took a more participatory dimension. In Spring 2015, the "Démocratie 2017” project was officially launched and I joined it in Fall 2015 as a PhD student invited to the steering committee of this cultural project, which will take place from November 2016 to March 2017. During this project we experienced that participatory projects are particularly demanding in terms of knowledge and skills. It required that we gain knowledge in participative animation's tools and in the political stakes of participation. Librarians took part to acquire new skills and worked on information retrieval using the bookmark tools Diigo. Information retrieval led by librarians seemed to be perfect situation to observe how librarians trained themselves to acquire new knowledge., This project will serve as my thesis which will focus on the link between knowledge and political action.

I make the hypothesis that, when studying the information retrieval process of librarians engaged in such projects, it will be possible to observe their information literacy as well as its impact on the participatory project of a public cultural establishment. To validate these assumptions, I used a theorical framework, built on philosophy and information sciences including the "archéologie des savoirs" de Foucault [2], the concept of information literacy of Pawley [3], and the concept of "information culture" of Le Deuff [4], to analyze the statistical treatment of information retrieval made by employees of the BML. Prior to detailing the methodology and the results of this study, it is essential to conduct a literature review, beginning with the matter of knowledge in participatory projects and then exploring the matter of librarians' informational skills. I will end the article with a discussion on the political role of libraries and the engagement of librarians in a public service for which neutrality is a central value [5].

\section{Literature Review}

Participatory projects have a multifaceted relationship with knowledge. Participation is often approached as a citizens / elected officials / technicians triothat, although it shows some shortcomings [6]), in particular due to excessive categorization, still allows to distinguish between various forms of knowledge gathered by the participants. Because of the entanglement of the roles between citizens and technician [7] [8], participatory projects also result in the development of new knowledge related to the context, to the territory, or to participation itself, both in theoretical and practical terms. We can even expect to see a professionalization of this participation [9] that might drive it away from the field of engagement [10]. So, while citizens and technicians assemble knowledge, they also generate new ones. But there is no research done on the conditions of these learnings. In this article I will attempt to fill this void by studying the specific case of librarians. 
There is an abundant literature analyzing the training dispensed by librarians to their publics to achieve information literacy and political literacy. Henri Maitles [11] noted that if political education has no conclusive effects, the political literacy provided by librarians should focus on skills to participation to politics and to political knowledge, more than on the working of political institution, to be more effective. For Elmborg [12], librarians had to focus not on transfer of information but on acquiring a critical conscience. For Smith [13], the critical literacy lead to a political agency in moving from individual point of view to a social one, and in requiring a assumed responsibility. Political action seems to required a political look on information. In this paper I will try to observe it.

On rarer occasions, that literature offered analyses on librarianship trainings aimed at teaching instructing skills [14]. Yet there is surprisingly sparse literature on how librarians wield their own information literacy while engaged in their professional activities. Education and information sciences focus on the training of students and children but rarely on the proficiency of the teachers and librarians themselves [15]. I would like to fill this silence in the literature is something with this study.

\section{$3 \quad$ Methodology}

\subsection{Theoretical framework}

Myresearch relied first on a philosophical approach to determine the type of political discourse of French libraries. The « archéologie des savoirs » of Michel Foucault [2], gave us a framework to study the sources that inform the political action of librarians, which include: key texts of French libraries including a Manifesto and classical texts; the orientation plan of the public library of Lyon; and, finally the information retrieval of librarians involved in the "Démocratie 2017" project. I will just focus on this last point ior this paper,. Second, my research stood on two political approaches of information literacy (IL): the critics of IL from Pawley [3], and the concept of culture of information of Le Deuff [4]. I used these approaches to build a theoretical framework for this specific case.

\section{According to Le Deuff, culture of information is eminently political and civic}

[16]. It "takes into account the necessity for the citizen to have pertinent resources available, so that they can form an opinion.” [4, p105]. For Pawley, information literacy requires the ability to put information on a political context. I wanted to measure inthis information retrieval study whether librarians had a political agenda and/or librarianship agenda.

2. According to Le Deuff, “[communicational culture] is closer to critical literacy and requires resistance capacities. There is a political and philosophical dimension centered more on the individual than on the citizen." [4, p 106]. Each individual gathers 
knowledge that allowed them to form an individual and critical analysis of the information they found. For Pawley, information literacy lead everyone to engage himself or herself [3]. Information looked for, selected, and absorbedreflected choices and values. Myinformation retrieval analysis will show if the tastes and interests of the individual take precedence over the collective values of the librarians as criteria for evaluation of information.

3. The phrase "culture of information" was inspired by the work of Major R. Owens and how he linkrf the matter of responsibility to information literacy. According to him, information retrieval committed us to act. Christine Pawley also used this notion of action around the concept of consumers-producers [3]. The trainer should not perceive the one intended to acquire information literacy as passive, but as able to create their own information. Both these theories of information literacy gave an important place to action made possible by information. I therefore, tried to find out to what extent the information retrieval done by the group revealed an active dimension.

\subsection{Statistical study}

The steering committee of the "Démocratie 2017" project conducted information retrieval work on the topic of the event. My article looks precisely into this information retrieval process, which is stored and compiled in a Diigo project The Diigo project is freely accessible. It is also diffused weekly via a Scoop-it.

Mystudy relied on a statistical treatment of the Diigo project to identify:

- $\quad$ Quantitatively: items, sources, type of sources, and form of items

- Qualitatively: topics related to the project, intellectual ou academic field of authors, and topics of the items.

I knew that this research had a bias inducted by the thema of the project itself. The action of librarians working on participatory projects and new democratic forms as well as the information they seek related to these projects wasnecessarily very political and very closed to some alternatives movements.

\section{$4 \quad$ Results and Discussion}

The Diigo of the Démocratie 2017 project added 125 items in eleven months. I studied the content of this information retrieval process from June 2015 to April 2016. Twelve participants contributed to the Diigo, including the eleven persons of the steering committee and myself. I published 4 out of the 125 items. Two members of the steering committee did not sign up. Three of the participants did not entereditems, six participantsentered fewer than the. The three agents who initiated the project entered 20 items, 30 items, and almost 60 items respectively. Those three agents began their data gathering work in in June 2015 while all the others began during fall. However, the time they started their participation was not the only explanation for their higher 
participation. These three agents worked in the "Society and Civilizations" department of the central library and political matters were at the core of their daily activities, as opposed to other members of the group who might have been working on more distant topics.

\subsection{Objective based approach}

Instead of showing a desire to prepare as a librarian, the Diigo data reveals that librarians involved in the project? desired to develop a unique view of the topic extending beyond the framework of the library.

Examining the 125 items by subject fields showed only 5 items from Library and Information Sciences (LIS). Three addressed new topics in librarianship: the common good of knowledge. Two others talked about political questions in libraries: burned libraries in the first example and participatory projects for the second. LIS seemed to be considered as another academic field, like the performing arts, medias studies, psychology, and anthropology. LIS is a potential source for this project, but not the main source.

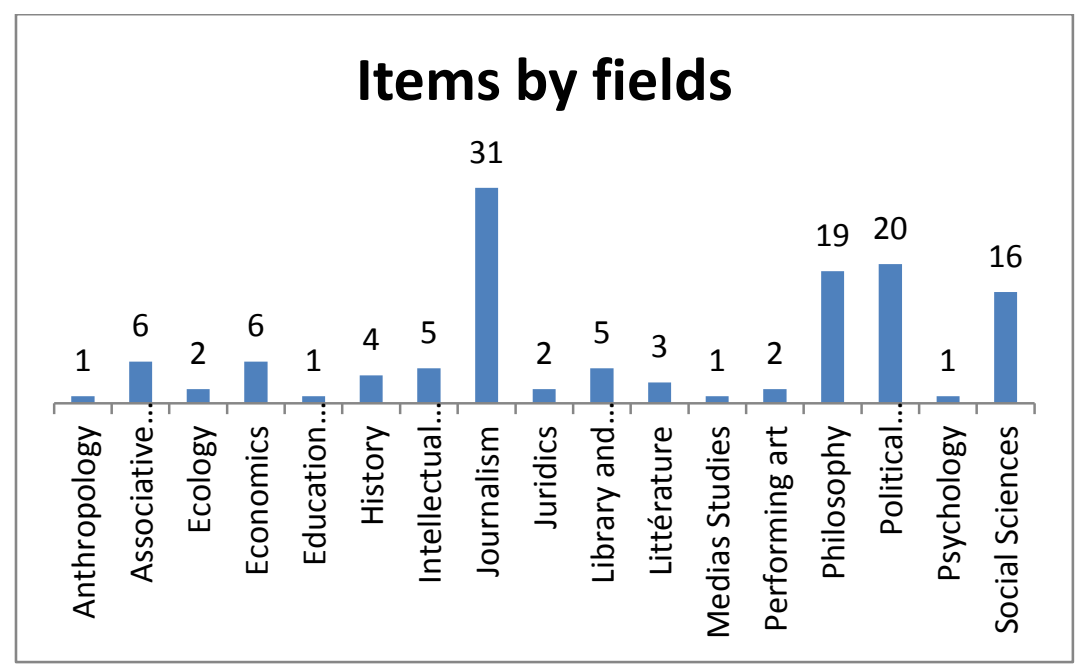

- $\quad$ Fig. 1. Items by fields

The main field of the items was, in fact, journalism (31 items or 25 percent out of 125). By journalism, I mean that the author of the item was a journalist who wrote with a journalistic orientation. There were 88 (90 percent) items in all other academic fields. The final six items were about associative activism or texts written to serve or present the activist project of an association. In the 88 items written with academic orientations, 19 (15 percent) were in philosophy, 20 (16 percent) were in political sciences, and 16 (13 percent) were in social sciences. The two last fields were not | surprising since the political and social sciences were related to the topic of the project and to the libary acquisitions areas of the leaders of the project. At first, the presence 
of itemsin philosophy could be seen as strange, but those items were essentially in political philosophy.

The 125 items come from 79 different sources. Sixty-three ( 80 pecent) of these sources were mentioned only once but 15 (12 pecent) were mentioned more than once, in particular France Culture (17 items) and Médiapart (8 items). The other sources were mentioned fewer than four times with the exception of the the catalogue of BML, whose use is described in the paragraph below. France Culture is a very high-level national public radio station where a lot of academics speak. This radio station leans more towards intellectuals than culture even though the latter is still largely represented. Médiapart is an online independent journal that aims to revive the tradition of journalistic investigation, calls for participation among its readers, and frequently organizes debates.

These data show that LIS and/or technical questions were not central in this information retrieval. The main use of this information retrieval was to train collaborators on this topic so that they can grasp the concepts in a more general sense and not solely in the context of libraries. Six items used the catalogue of the BML as their source which pointed out that some of the useful documents were already in the collection. It process also allowed the team to identify potential participants. The list of lecturerd invited to talk during the future events (November 2016 to March 2017) was the same than the list of authors identified? in the information retrieval. Some are mentioned? numerous time such as Rancière and Fraser in philosophy, Wahnich and Rosenvallon in history, and Coriat in economy.

This lead me to think that, for the librarians doing this information retrieval, the point was not to find data allowing them to simply do their job but to do their work differently. Likewise, they did not simply question today's democracy; they also questioned the potential for an emerging democracy. As such, the Diigo project showed a civic rather than a technical informational culture. In fact, if the project called into question what libraries usually stand for, then the information retrieval process largely went beyond a technical objective. It allowed librarians to question their role in society, facing social and civic practices they were not familiar with. It revealed the possible emergence of a new kind of librarian. French librarians have long been accused of being "Télérama", that is to say that, despite being left-leaning they had an elitist discourse on the democratization of culture. In other words, it was OK to watch TV but only if you watched good movies. Entertainment was only acceptable as long as you picked and chose. This type of discourse had long been relayed by librarians in the way they selected documents they deemed good and of appropriate cultural level for their public [17]. Yet there is a complete absence of any reference to Télérama on the Diigo platform. In fact, Télérama may have been replaced by France Culture as a new cultural reference served as an indicator to the importance of the academic fields we observed. While the objective for librarians here was not to develop their librarianship skills, they clearly tried to identify experts in democracy and participation that were almost exclusively academics. It showed a certain position of humility with librarians clearly stating that they were not experts as opposed to the Télérama librarians. In opposition, if they are not experts, they had the keys to contextualize, to point out the 
stakes, and to build and help to build a political discourse. This was a first step to moving a cultural action into a political action.

\subsection{Value-Based Approach}

The items in the Diigo project leaned heavily on the left or sometimes far left side of the political spectrum. As it allowed, on one hand, the training of agents and, on the other end, the creation of a list of potential participants, the whole project was characterized by this left-leaning tendency. Most of the items were critical of democracy and representation and called for an increased participation in the political field and for more empowerment for each and every person from a collective point of view. These were signs of a drifting away from the usual political parties as well as an interest for radical democracy. Facing the difficulty of distinguishing between the nuances of the left, I focused on the identification of items from the right or neutral. I considered the institutions as neutral if they offered services by the state. If they did not, I assigned them to the political party in power at the time of creation of the content or to the stance of the participants taking part. So, a radio show on France Culture could not be considered as neutral when only left or far left academics took part. While I was able to find four neutral items, I could not find one expressing a right-wing stance. As I said earlier, this result was not very surprising due to the thema of the project. However, this result was not in complete opposition with the generally left-leaning tendencies of French libraries and with the values of librarians. In an article of the activism of librarians, Camille Hubert expressed a real difficulty in identifying right-leaning librarians and the only person who accepted her invitation to talk to her asked to do so anonymously [18].

To go further in the analysis of the content of the items, I looked at how they fit or did not fit in the four majors topics of the project as defined by the steering committee: democracy, participation, empowerment, and commons.

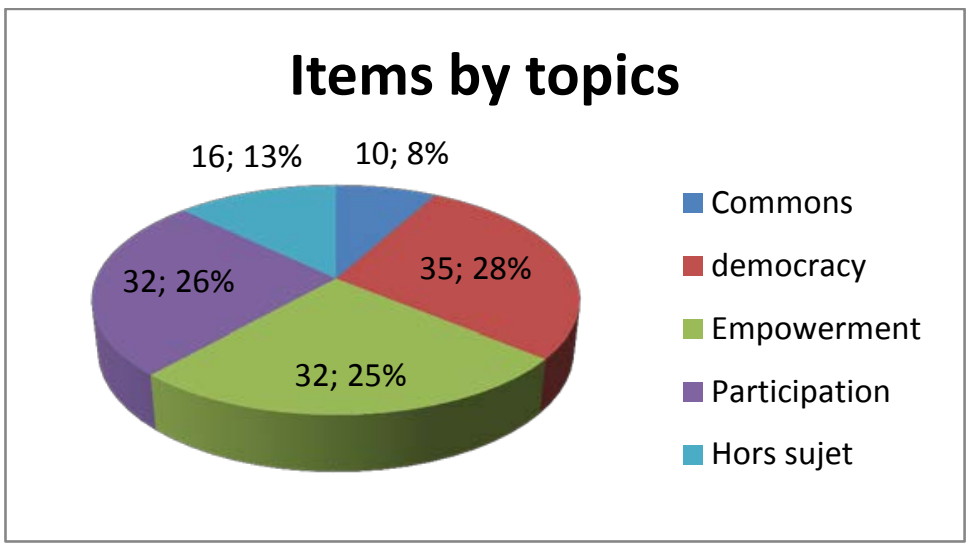

- $\quad$ Fig. 2. Items by topics. 
There was an almost perfect equality between three topics: democracy, empowerment, and participation. The topic of Commons was weaker compared to the others but the specialization of this topic, its novelty, and the low number of people working on this explained it. What was really surprising was that 13 percent of items did not fit into one of the major topics. All these items were related to political questions and,specifecally, to critics of today politics including critics of political parties, governmentality, and use of algorithms in politics. This 13 percent of items showsed that this information retrieval was also a place for more activist positions and global thoughts about the society.

The items by type of sources also showed a ambivalent place for institutions. Only seven items had a cultural or political institution, , such as a museum, governemental website, or governemental agency, as a source. I also could have considered academic journals and research centers are institutions because universities are public in France and the national radio France Culture, could be considered a national institution. If these sources are included, then 47 percent of the items were cultural or political institutions.

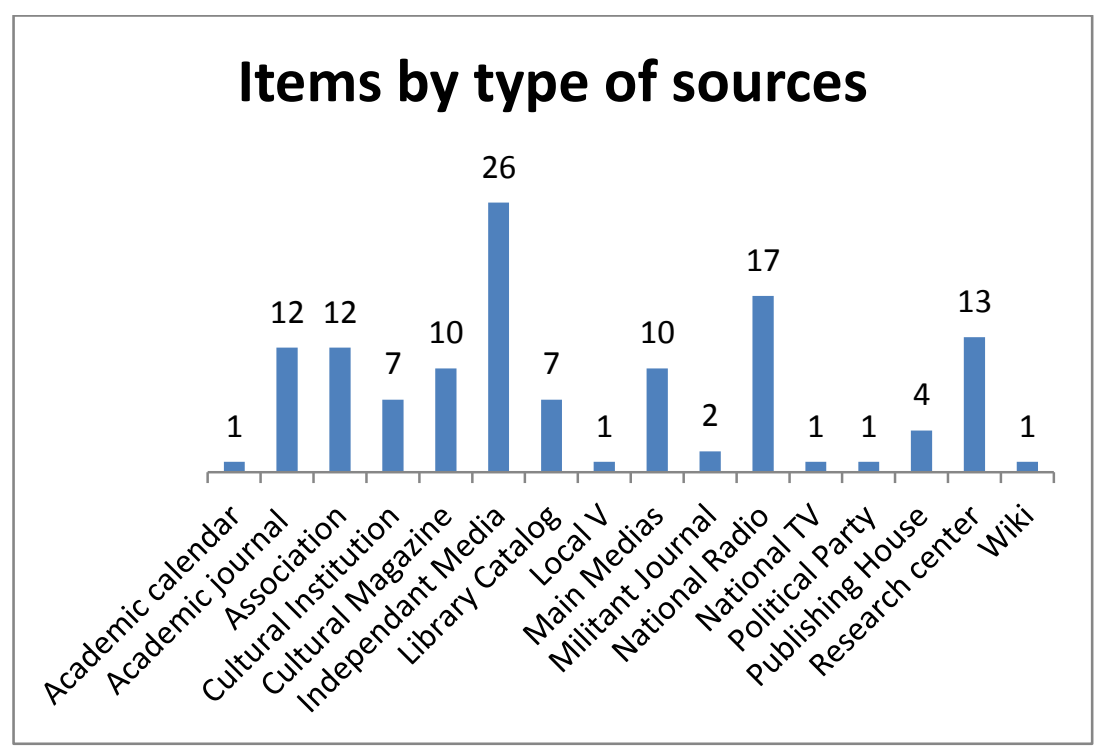

- $\quad$ Fig. 3. Items by type of sources.

Yet, most of the researchers and well as those affiliated withFrance Culture, independant media, and even major media were more apt to express a critical and political thought than an institutional speech. I could say that the tradition of involvement of intellectuals who speak publicly has been to call others to concrete actions and participate with activists in the field. Adding to this, 32 percent of the items clearly sources clearly identified as activist sources such as associations, independant media, and militant journals. The militant position was far away central to this information retrieval. 
This reflects the problem of neutrality in French institution workers, including librarians [19]. Civil servants are not supposed to let the politicians dominate? aloud the political discourse. This does not mean that libraries' actions do not have a political influence or stance but this has not to be presented as political. Despite this, the study of the types of sources shows an emphasis on clear stands. In other words, while the selection shows a drifting away from the value of neutrality, it shows maybe a closer proximity to some other collective value for French librarians. The first collective value could be the rejection of right and far-right opinions. More interesting is another collective value related to the role of libraries in the society. If in 2005, D. Lahary [20] defined that the new generation of librarians were de-politized, maybe this generation is only approaching the political role of libraries from another angle that we still have to define. The neutrality of the library does not have to be a principle but the consequence of its assumed political role [21]. In the end, the information retrieval process revealed a critical approach through a questioning of the notion of neutrality, preferring a refocusing on the missions of libraries and their responsibilities.

\subsection{Action-Based Approach}

As we saw earlier, studying the sources of items by type also showed the importance of the academic environment; 27 items were research centers and academic journals: 27 items. I also studied the content of these items depending on their form. Unsurprisingly considering the previous results, I noticed a strong predominance of academic papers and podcasts. This result could even be increased, if we considered that 90 percent of the participants in the radio shows were academics. Librarians seemed to be hiding their actions behind those of academics.

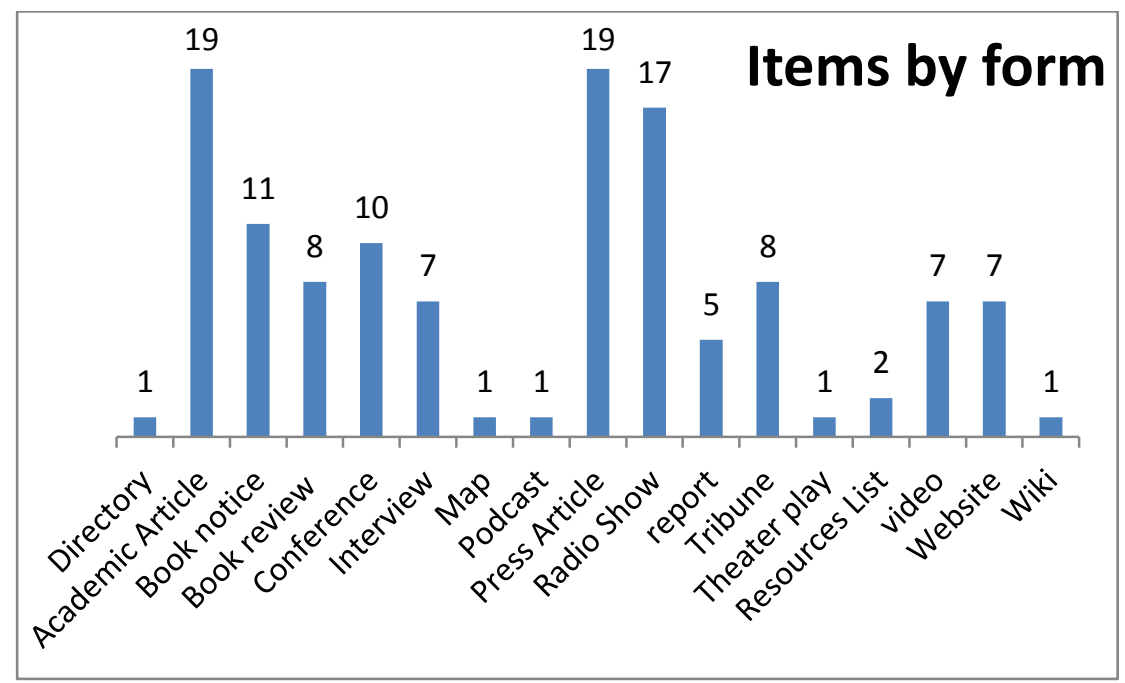

Fig. 4. Items by form 
By proclaiming their non-specialist status, librarians remained behind the scened of political action and, in doing so, partly withdrew from it. Indeed, political actors put themselves forward and take responsibility [22].

On the other hand, the information gathered with Diigo was transformed in several ways: (1) into a Scoop.it; (2) into potential participants; and, (3) into information sheets on the topics, for the agents but also later for the public, in particular through the work done with schools and teachers. In this regard, I could say that the steering committee was a consumer-producer [3]. Likewise, some of the selected tools and practices showed the librarians' desired to try different relations with the public and to question the library's capacity for being truly participatory. Facets of the work got close to the way John Dewey analyzed democratic renewal through participation [23]. I saw this in the notion of experimentation, the projection into a future that librarians will be part of, and in the criteria for the selection of the items.. I could note a desire "to be situated in the political action and not solely focused on the transmission of knowledge" [24].

Topics like emancipation or empowerment were very present in the information gathered, so it was important not to dismiss them as anecdotal. Indeed, although French libraries lacked any law clearly defining their missions, they agreed to say that their function was to contribute to the emancipation of citizens. Democratization was key in this emancipation, but is largely being questioned nowadays [25]. This information retrieval traced the contours of a different reflection on emancipation, less top-down and more experimental. Librarians seemed to embrace their role not as pillars of democracy, but as active agents. This action toos different forms:

- $\quad$ having new democratic forms experienced through participation emancipation inspired by John Dewey [23];

- $\quad$ convincing the public of their ability to act through equality in the intellectual debate through a definition of emancipation closer to the one thought by Jacques Rancière [26])

- offering a new way to think about goods as common goods, thus a emancipation more based on digital citizenship and texts by philosophers Dardot and Laval [27].

The agents of the BML regretted not being part of a true debate event and saw the Démocratie 2017 project as a way to fill this void. The point was not just to propose debates but to embrace the intensity or even the possible conflicts of the debates. Accepting this agitation was one of the new orientations that the information retrieval performedby the group seems to be showing, hence the choice of items, strongly oriented towards change, reform, and a renewal of democracy. The knowledge assembled was revelatory of a desire for action, of a will to think the library as a political actor in its capacity to offer places for debate. In other words, to be a true Habermasian public space [28].

\section{Conclusion}

In a project such as the one undertaken by the BML, the information retrieval done by 
the organizing team revealed a new approach to the political role of libraries. It showed us the portrait of a new generation of librarians who accepted their political role as civil servants / citizens, moving further away from librarianship techniques, but moving closer than ever to the assertion of a responsibility towards society. However, this desire to take part in political action seemed to be in conflict with the values of libraries that correspond to another way of thinking the role of public cultural institutions: neutrality, democratization and emancipation through culture rather than through action. This difficult convergence between two representations of libraries does not seem to result from a lack of training of the librarians in terms of informational skills, but rather from a lack of political culture. By this I mean that librarians nowadays had trouble identifying French librarianship thinkers, to position themselves in a tendency, a history, to feel at one with it, while being able to make it their own and criticize it, and adapt it to their current problems, and in a way rekindle their vocation. The tendency in Anglo-Saxon countries toward the development of a critical library science lets us see promising possibilities in the domain of the political action of librarians.

\section{References}

[1]Bats, R. Les enjeux et les limites de la participation : le rôle des bibliothèques. In Construire des pratiques participatives dans les bibliothèques (pp. 58-65). Villeurbanne, France: Presses de l'Enssib, (2015).

[2]Foucault, M.. L'archéologie des savoirs. Paris, Gallimard. (1969).

[3]Pawley, C. Information Literacy: a contradictory coupling? Library Quaterly, 73(4), 422-452. (2003).

[4]Le Deuff, O. La culture de l'information: Quelles «littératies » pour quelles conceptions de l'information? Presented at the VI.ème Colloque international du chapitre français de l'ISKO, Toulouse, France. (2007).

[5]Bats, R. Post Charlie Hebdo: The French libraries between freedom of expression and neutrality of the cultural institutions. Presented at the Bobcatsss 2016, Lyon, France. (2016).

[6]Mazeaud, A. Citoyen/Élu/Technicien. In I. Casillo, R. Barbier, L. Blondiaux, J.-M. Fourniau, F. Chateauraynaud, R. Leferbvre, ... D. Salles (Eds.), Dictionnaire critique et interdisciplinaire de la participation. Paris: GIS Démocratie et Participation. Retrieved from http://www.participation-et-democratie.fr/es/dico/citoyenelutechnicien (2013).

[7]Nez, H. Savoir d'usage. In I. Casillo, R. Barbier, L. Blondiaux, J.-M. Fourniau, F. Chateauraynaud, R. Lefebvre, ... D. Salles (Eds.), Dictionnaire critique et interdisciplinaire de la participation. Paris: GIS Démocratie et Participation. Retrieved from http://www.participation-et-democratie.fr/es/dico/savoir-dusage (2013).

[8]Leclerc, O. Expert. In I. Casillo, R. Barbier, L. Blondiaux, J.-M. Fourniau, F. Chateauraynaud, R. Lefebvre, ... D. Salles (Eds.), Dictionnaire critique et interdisciplinaire de la participation. Paris: GIS Démocratie et Participation. Retrieved from http://www.participation-et-democratie.fr/es/dico/savoir-dusage. (2013).

[9]Mazeaud, A., \& Nonjon, M. Professionnel. In I. Casillo, R. Barbier, L. Blondiaux, J.-M. Fourniau, F. Chateauraynaud, R. Leferbvre, ... D. Salles (Eds.), Dictionnaire critique et 
interdisciplinaire de la participation. Paris: GIS Démocratie et Participation. Retrieved from http://www.participation-et-democratie.fr/es/dico/citoyenelutechnicien (2013)

[10]Blondiaux, L., \& Fourniau, J.-M.. Un bilan des recherches sur la participation du public en démocratie : beaucoup de bruit pour rien ? Participations, 1(1), 8. (2011)

[11] Maitles, H. Teaching Political Literacy, Scottish Educational Research Association Annual Conference. (1997).

[12] Elmborg, J. Critical Information Literacy: Implications for Instructional Practice. The Journal of Academic Librarianship, Volume 32, Number 2, pp 192-199 (2006)

[13] Smith, L. Critical Information Literacy instruction for the development of political agency.

Journal of Information Literacy, 7 (2). (2013)

[14]White, K. L., \& Gilliland, A. J. Promoting Reflexivity and Inclusivity in Archival Education, Research, and Practice. Library Quaterly, 80(3), 231-248. (2010).

[15]Martins, F. Information literacy in areas of cognitive science and information science. Conférence presented at the Conférence Enssib, France. Retrieved from http://www.enssib.fr/conference-fernanda-martins (2016).

[16]Deuff, O. L. Penser la conception citoyenne de la culture de l'information. Les Cahiers du numérique, 5(3), 39-49. (2010).

[17]Calenge, B. Entre le lecteur et la lecture, quelle bibliothèque ? Bertrand Calenge : carnet de notes [blog]. Retrieved from https://bccn.wordpress.com/2012/02/27/entre-le-lecteur-et-la-lecture-quelle-bibliotheque/ (2012, février).

[18]Hubert, C. Bibliothécaires et militantisme: neutralité et pratiques professionnelles. Villeurbanne, Rhône, France. (2013).

[19]Bats, R. Libraries after Charlie: from Neutrality to Action. Library Trends, to come(to come), to come. (2016).

[20]Lahary, D. Le fossé des générations. Bulletin des Bibliothèques de France, (3). Retrieved from http://bbf.enssib.fr/consulter/bbf-2005-03-0030-005 (2005).

[21]Jaeger, P. T., Gorham, U., Bertot, J. C., \& Sarin, L. C. Democracy, neutrality, and value demonstration in the age of austerity. Library quarterly: Information, community, policy, 83(4), 368-382. (2013)

[22]Tassin, É. Ce que l'action fait à l'acteur. Tumultes, 2014/1(42), 41-54. (2014).

[23]Dewey, J. Le public et ses problèmes. (J. P. Zask, Trans.) (Vols. 1-1). Paris, France: Gallimard. . (2010).

[24]Bertrand, A.-M. Les bibliothèques sont filles des Lumières. Quoique.... Bulletin des bibliothèques de France, (5). Retrieved from http://bbf.enssib.fr/consulter/bbf-2015-05-0044-005 (2015).

[25]Cousin-Rossignol, G., Les bibliothèques face à «l'échec de la démocratisation culturelle ». Villeurbanne, Rhône, France. (2013).

[26]Rancière, J. Le maître ignorant: cinq leçons sur l'émancipation intellectuelle. Paris, France: Fayard. (2009).

[27]Dardot, P., \& Laval, C. Commun: essai sur la révolution au XXIe siècle. Paris, France: la Découverte, (2015).

[28]Habermas, J. L'espace public: archéologie de la publicité comme dimension constitutive de la société bourgeoise. (M. Buhot de Launay, Trans.) (Vols. 1-1). Paris, France: Payot. (1993). [29]Arstein, S. A Ladder of Citizen Participation. JAIP, vol. 35, no 4, (pp. 216-224). (1969). 
